\title{
2
}

\section{GENE DELIVERY IN THE ICU}

\author{
Daniel J. Weiss M.D., Ph.D. \\ Fred Hutchinson Cancer Research Center, Seattle, WA 98109
}

\section{INTRODUCTION}

There are many potential applications for gene therapy in the intensive care setting. Gene transfer driven expression of substances that interfere with inflammatory mechanisms may modulate the acute inflammation accompanying many critical illnesses. Similarly, transgene expression that restores production of crucial biological mediators affected by the acute illness may be beneficial. Transgene expression need also not be limited to naturally occurring biological products. For example, cDNA can be constructed that will encode for novel synthetic anti-microbial peptides with potential for use in sepsis or other infections. However, despite these possibilities, gene therapy for critical illnesses remains an underexplored area.

The focus for gene therapy in the ICU will likely be on transient high level gene expression. In this context, gene therapy can be viewed more as a pharmacologic tool for providing a therapeutic mediator rather than a means for long-term correction of genetic defects such as cystic fibrosis or hemophilia. To achieve successful high level gene expression, effective delivery of gene transfer vectors to target tissues and organs needs to occur. This is a potentially significant problem for ICU-based gene therapy as effective vector delivery to an injured or diseased organ may be difficult. In particular, vector delivery may be especially problematic in lung. Effective gene delivery to airway and alveolar epithelium in normal lung is impeded by naturally occurring barriers of glycocalyx, mucins and surface fluids lining the airways. These barriers will certainly be increased in acute lung injury in which edema, increased mucin production, and inflammatory cellular debris will further impede effective access of vectors to epithelial cells. 


\section{GENE DELIVERY TO NORMAL AIRWAY AND ALVEOLAR EPITHELIUM}

\section{General Techniques}

Current techniques of delivering gene transfer vectors to airway and alveolar epithelium include nasal deposition of vector (1) direct instillation of vector into the trachea or lower airways using a catheter or bronchoscope (2-4) and aerosolization and inhalation of vectors (5-7). Nasal deposition in obligate nasal breathers such as rodents can be effective in distributing vector throughout the lower airways (5). However, in non-human primates and in humans, gene expression resulting from nasal deposition of vector is generally limited to nasal epithelial.

There are several approaches to direct vector instillation into the trachea or lower airways. In small animal models, transtracheal puncture with a small gauge needle is commonly used $(8,9)$, whereas bronchoscopic administration of vector is usually performed in larger animal models (primates) and in patients $(10-12)$. Whatever the method, direct vector instillation generally results in heterogenous distribution to limited portions of lung $(10,12)$. Multiple instillations are required to achieve more widespread vector distribution. Moreover, the resulting transgene expression is usually more evident in epithelium of larger proximal airways. Catheter-directed instillation, particularly when using a bronchoscope, generally requires topical analgesia and sedation to be performed comfortably and safely (1012).

Aerosol administration of nebulized vector solutions can result in more diffuse transgene distribution throughout the lung and in increased distribution to distal airway and alveolar epithelium. However, large amounts of vector are required as material is lost by deposition in the aerosolization equipment and on oro- or nasopharyngeal, laryngeal, or upper airway mucosa (5-7). A recent technique has been developed using a spray device directed through a bronchoscope (13). This approach allows for positioning of the bronchoscope at the carina or in either of the mainstem bronchi and spraying vector solution more effectively into more distal airways. While this method has met with some success, it has not been widely utilized.

\section{Adjunct Methods}

Several approaches have recently been shown in animal models to enhance vector delivery using direct airway instillation techniques. Administering adenoviral vectors in either 10 or $25 \mathrm{mg} / \mathrm{ml}$ solutions of the synthetic surfactant Survanta increased reporter gene activity in rabbit lung parenchyma $(14,15)$. Expression in trachea and main bronchi was decreased 
suggesting that the surfactant vehicle resulted in more effective distribution of vector to the lower airways (14). Delivery of Adlac- $Z$ in a $50 \%$ Survanta solution also increased in situ $\beta$-gal activity in rat lungs (16). In contrast, transgene expression mediated by naked DNA in mouse lungs was decreased when the DNA was administered using a different synthetic, lipoprotein-free surfactant solution (Exosurf)(17). The mechanism by which gene expression was inhibited remains unclear. Survanta had no effect on naked DNAmediated gene expression in cultured lung epithelial cells or cultured lung fibroblasts but did inhibit expression mediated by cationic liposomes (18). Naturally occurring bovine and rabbit surfactants also inhibited cationic liposomal-mediated gene expression in cultured lung epithelial cells (19). In these studies, mixing of surfactant components with those in the cationic liposomes probably resulted in disruption of the liposomes with subsequent decrease in gene transfer (19).

The majority of receptors for adenoviral, adeno-associated viral, and retroviral vectors are located on basolateral surfaces of airway epithelial cells rather than the luminal surfaces that are exposed to vectors following intratracheal delivery (20-22). Intact tight junctions between epithelial cells prevent access of vectors to the basolateral surface receptors and decrease the overall effectiveness of intratracheal gene delivery. Recent approaches have used EGTA or detergent to disrupt tight junctions between mature ciliated airway epithelial cells and allow access of vector to binding sites on basolateral cell surfaces. Both methods have resulted in enhanced adenoviralmediated gene expression in both cultured epithelial cells and in mouse lung in vivo (23-25).

Precipitation of adenoviral and adeno-associated viral vectors with calcium phosphate has also been demonstrated to enhance adenoviral and adenoassociated viral mediated gene expression in lung epithelial cells and in mouse lung in vivo $(26,27)$. The calcium phosphate precipitation may enhance non-specific viral uptake by the luminal surfaces of airway epithelial cells and may also increase viral release from endosomes resulting in increased viral expression.

A summary of currently available delivery techniques is shown in Table 1 . While several of the adjunct approaches can improve the efficiency of gene delivery in vitro and in animal models, it is unclear whether they can be practically utilized for clinical gene therapy. Moreover, none of these techniques have been investigated in injured or diseased lungs except for the use of PFC liquids, discussed below. 


\section{Table 1. Adjunct Methods for Delivery of Gene Transfer Vectors in Normal Lungs}

\begin{tabular}{|c|c|}
\hline $\begin{array}{l}\text { Surfactants } \\
\text { Jobe et al., } 1996 \\
\text { Katkin et al., } 1997 \\
\text { Factor et al., } 1998\end{array}$ & $\begin{array}{l}\text { Effect } \\
\text { Increased adenoviral-mediated transgene activity in rabbit lungs } \\
\text { Increased adenoviral-mediated transgene activity in rabbit lungs } \\
\text { Increased adenoviral-mediated transgene activity in rat lungs }\end{array}$ \\
\hline $\begin{array}{l}\text { Tsan et al., } 1997 \\
\text { Duncan et al., } 1997\end{array}$ & $\begin{array}{l}\text { Decreased cationic liposomal transfection of cultured cells } \\
\text { Decreased cationic liposomal transfection of cultured cells }\end{array}$ \\
\hline $\begin{array}{l}\text { Raczka et al., } 1998 \\
\text { Calcium Phosphate }\end{array}$ & Decreased naked DNA-mediated transfection in mouse lungs \\
\hline Fasbender et al., 1998 & $\begin{array}{l}\text { Increased adenoviral-mediated transgene activity } \\
\text { in cultured cells and mouse lung }\end{array}$ \\
\hline $\begin{array}{l}\text { Lee et al., } 1999 \\
\text { Walters et al., } 1999\end{array}$ & $\begin{array}{l}\text { Increased adenoviral-mediated transgene activity in mouse lung } \\
\text { Increased AAV-mediated transgene activity in cultured cells } \\
\text { and in mouse lung }\end{array}$ \\
\hline $\begin{array}{l}\text { EGTA } \\
\qquad \text { Wang et al., } 1999\end{array}$ & Increased adenoviral and retroviral-mediated transgene activity \\
\hline $\begin{array}{l}\text { Chu et al., } 1999 \\
\text { Johnson et al., } 1999\end{array}$ & $\begin{array}{l}\text { Increased adenoviral-mediated transgene activity in mouse lung } \\
\text { Increased adenoviral-mediated transgene activity in cultured } \\
\text { human airway epithelial cells }\end{array}$ \\
\hline $\begin{array}{l}\text { Detergent } \\
\quad \text { Parsons et al., } 1998\end{array}$ & $\begin{array}{l}\text { Increased adenoviral-mediated transgene activity in murine } \\
\text { nasal epithelium }\end{array}$ \\
\hline $\begin{array}{l}\text { Perfluorochemical Liquid } \\
\text { Lisby et al., } 1997 \\
\text { Weiss } \text { et al., } 1999 a \\
\text { Weiss et al., } 1999 b \\
\text { Weiss et al., } 1999 c\end{array}$ & $\begin{array}{l}\text { Increased adenoviral-mediated transgene activity in rabbit lungs } \\
\text { Increased adenoviral-mediated transgene activity in rodent lungs } \\
\text { Increased liposomal-mediated transgene activity in rat lungs } \\
\text { Increased AAV-mediated transgene activity in mouse/rat lungs }\end{array}$ \\
\hline
\end{tabular}

\section{PERFLUOROCHEMICAL LIQUIDS AND LUNG GENE DELIVERY}

A promising approach for increasing the effectiveness of direct instillation techniques is the use of perfluorochemical liquids to flush vectors into the lung. Perfluorochemical (PFC) liquids are chemically inert fluorinated carbon chain liquids that are excellent solvents for $\mathrm{O}_{2}, \mathrm{CO}_{2}$, and other gases yet are immiscible with aqueous and lipid solutions $(28,29)$. Other properties include high density and low surface tension which allow PFC liquids to distribute throughout communicating airways and spread over alveolar walls following instillation into lungs (29). These compounds were first demonstrated in the mid $1960 \mathrm{~s}$ to support effective oxygenation and survival of animals immersed in PFC liquid (28). PFC liquids have been subsequently used for supporting gas exchange in the lung (ie. liquid ventilation). Clinical experience with the PFC liquid perflubron (LiquiVentR Alliance Pharmaceuticals, San Diego, CA) in both children and adults demonstrated that this compound can be safely instilled in intubated, mechanically ventilated patients with minimal toxicity allowing for effective gas exchange $(30,31)$. The volatile PFC liquids clear by evaporation within 24 hours. 
Perflubron was first used to enhance adenoviral-mediated gene expression in intubated, ventilated rabbits (32). We subsequently developed a technique using transtracheal puncture for flushing adenoviral, AAV, or cationic liposomal vectors into lungs of spontaneously breathing rodents with a single dose of PFC liquid $(9,33,34)$. Use of PFC liquids in this manner increased total quantitative transgene expression and enhanced transgene distribution within and between lung lobes (Fig. 1)(9,33,34). Transgene expression was particularly improved in distal airways and alveoli. Since there was no need for intubation and assisted ventilation, the procedure was well tolerated and large numbers of animals could be easily and efficiently studied. Preliminary experiments in non-human primates (rhesus macaques) have demonstrated that a single dose of PFC liquid administered through a bronchoscope was both well tolerated by the animals and similarly resulted in improved adenoviral mediated-gene distribution in the lung.

There are several mechanisms by which PFC liquids might result in enhanced gene expression and in distribution of gene expression. The PFC liquids likely act by flushing droplets of vector solutions further into and more uniformly throughout the lung than can be accomplished with either catheter-directed or aerosol administration of vectors. The PFC liquids may also transiently displace mucins and surface fluid lining layers allowing better access of vectors to epithelial cells. This is further discussed below with consideration of techniques for gene delivery to injured lung. PFC liquids also appear to be ingested by alveolar macrophages following instillation into lung. The macrophages are subsequently less able to phagocytose and inactivate adenoviral vectors presumably allowing for more vector available for epithelial cell transduction (35).

\section{GENE DELIVERY TO ABNORMAL OR INJURED LUNG}

\section{Access to the Lung in Critically III Patients}

Many critically ill patients will be endotracheally intubated and sedated allowing easy access to the lower airways using direct instillation (bronchoscopic or catheter) techniques. Aerosol administration can also be used with ventilator tubing although this approach is inefficient as much of the aerosol is deposited in the tubing, endotracheal tube, or upper airways. Non-intubated critically ill patients will require the same considerations as less ill patients: adequate local anesthesia and sedation for use of bronchoscopic or catheter-directed instillations. These may be easier to accomplish in many respects in an ICU than in an outpatient or clinic setting. 

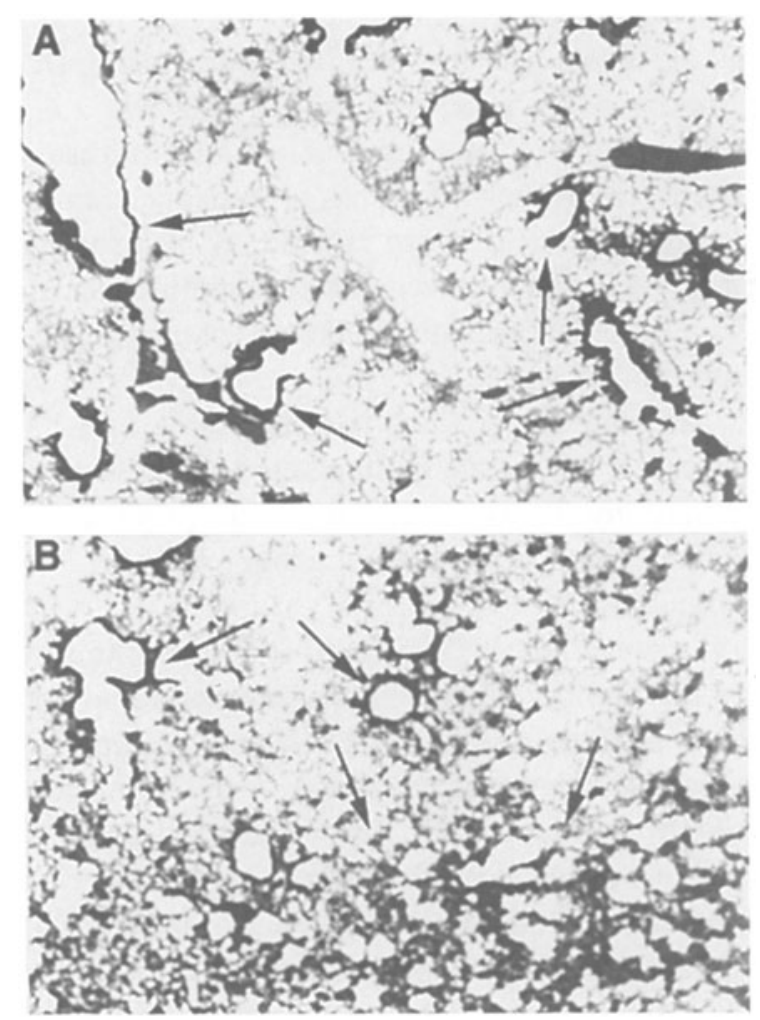

Figure 1. Low power photomicrographs of Sprague-Dawley rat lungs harvested 3 days after instillation of Adlac-Z demonstrate patchy, heterogenous activity predominantly in large proximal airways (arrows, $\mathbf{A}$ ). In contrast, rats instilled with Adlac-Z + PFC liquid demonstrate more widespread and diffuse activity both in larger and smaller airways as well as in alveoli (arrows, B). Original magnification $100 \mathrm{X}$.

\section{Barriers to Gene Delivery in Abnormal Lung}

Gene delivery to lung in the ICU will likely be done in the setting of injured or diseased lungs in which airways and alveolar spaces may be filled with edema, mucins, or inflammatory debris. However, methods of direct instillation and aerosol administration of vectors have been mostly evaluated in normal animal lung models $(3,6)$. There is little available information on how to overcome these barriers to achieve effective gene delivery.

A variety of barriers may impede access of vectors to airway and alveolar epithelial cells in injured or diseased lung. Mucins lining the airways have been demonstrated to decrease the effectiveness of adenoviral-mediated gene transfer (36). Removal of the transmembrane mucin glycoprotein MUC-1 by treatment with neuraminidase improved subsequent adenoviral-mediated gene transfer to cultured human airway epithelial cells (37). Similarly, in cultured 
cells coated with sputum from cystic fibrosis patients, treatment with recombinant human DNAse but not mucolytic agents, including Nacetylcysteine, alginase, or lysine improved adenoviral and cationic liposomal-mediated gene transfer to these cells (36). In a related study using sheep trachea in organ culture, removal of mucin resulted in a 25 -fold increase in cationic liposomal-mediated gene expression (38). These latter studies illustrate the role mucin lining layers may play in impeding adenoviral and liposomal-mediated gene delivery to lung, problems that would certainly be exacerbated in lung diseases that include increased mucin accumulation.

Adenoviral-mediated gene transfer to airway epithelium in mouse lung was decreased in animals with bronchopulmonary inflammation induced by prior inoculation with a mucoid Pseudomonas aeruginosa (39). Similarly adenoviral-mediated gene expression was decreased in nasal epithelium of mice previously inoculated with $P$. aeruginosa (23). Nonspecific inflammatory changes and elevation of pro-inflammatory cytokines in bronchoalveolar lavage fluid have also been associated with decreased adenoviral-mediated gene transfer and expression in rodent lung (40). Treatment of animals with dexamethasone to reduce inflammatory changes was accompanied by increased adenoviral-mediated gene expression in lung (40). Other potential barriers to effective vector delivery include edema and pulmonary hemorrhage. Although these have not been specifically evaluated in the context of lung gene therapy, in essence, any pathologic process that results in airway or alveolar filling may potentially impede vector delivery.

\section{Perfluorochemical Liquids and Gene Delivery to Injured Lung}

Although helpful in understanding factors associated with the effectiveness of vector delivery to airway epithelium, the above studies have not yet yielded effective strategies for improving gene delivery in vivo to injured lungs. In this respect, use of PFC liquids during vector instillation may provide a useful method of gene delivery to injured lungs. Clinical studies of liquid ventilation as well as observations in animals with experimentally-induced lung injury undergoing liquid ventilation demonstrate that perflubron improves oxygenation and lung mechanics $(30,41-43)$ and decreases the amount of lung injury observed on histopathologic specimens $(44,45)$. Moreover, use of perflubron decreased the amount of edema, bleeding, and neutrophil influx into injured lungs $(41,46,47)$. The level of the pro-inflammatory cytokines IL$1 \beta$ and IL-6 as well as total white cell and neutrophil count were reduced in BAL fluid collected from patients with acute respiratory distress syndrome (ARDS) undergoing liquid ventilation compared to fluid ARDS patients managed with conventional gas ventilation (31). These collected observations suggest that use of PFC liquid may be beneficial in the setting of acute lung injury. 


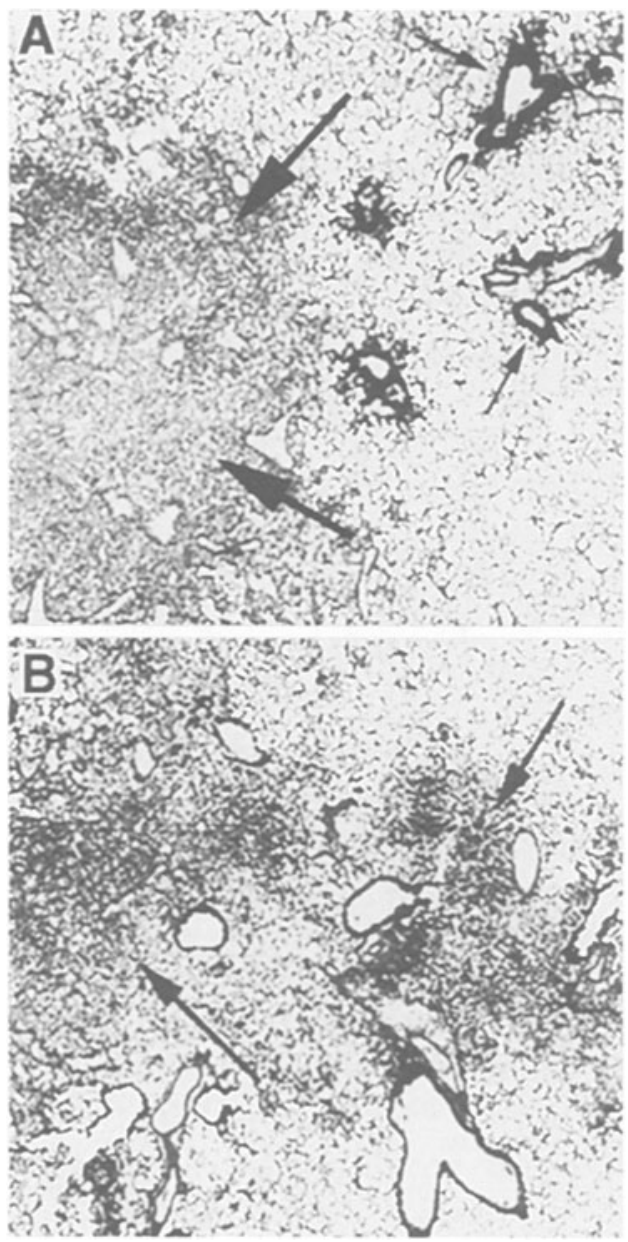

Figure 2 Lungs from GM-CSF knockout mice harvested 3 days after instillation with Adlac- $Z$ demonstrated robust $\beta$-gal expression in larger and medium-sized airways in normal lung regions (small arrows, $\mathbf{A}$ ). Little $\beta$-gal activity was observed in abnormal lung regions of alveolar filling with surfactant and protein debris in knockout mice receiving Adlac-Z (large arrows, $\mathbf{A}$ ). In contrast, knockout mice instilled with Adlac-Z + PFC liquid demonstrated activity in larger and medium sized airways as well as in small airway and alveoli in areas of alveolar filling (small arrows, B). Original Magnification 100x.

Perflubron has also been observed to displace mucins out of the airways and has been used to lavage injured lungs to remove mucins and inflammatory debris $(48,49)$. We reasoned that PFC liquids may generally be able to displace mucins, edema, and other inflammatory debris allowing better access of gene transfer vectors to epithelial cells. To evaluate this hypothesis we evaluated PFC liquid effect on adenoviral-mediated gene expression in transgenic GM-CSF knockout mice, which develop progressive alveolar filling with protein and surfactant debris. Use of PFC liquid enhanced adenoviral-mediated expression in both normal and diseased areas of lung $(50,51)$ (Fig. 2). There was no difference in the content of alveolar debris in 
knockout mice treated with PFC liquid compared to knockout mice receiving vector alone. We reason that the PFC liquid transiently displaced the debris allowing vectors to penetrate into areas of chronic alveolar filling. This allowed epithelial cell transduction in areas of injured lung that were not transduced in animals that received vector alone.
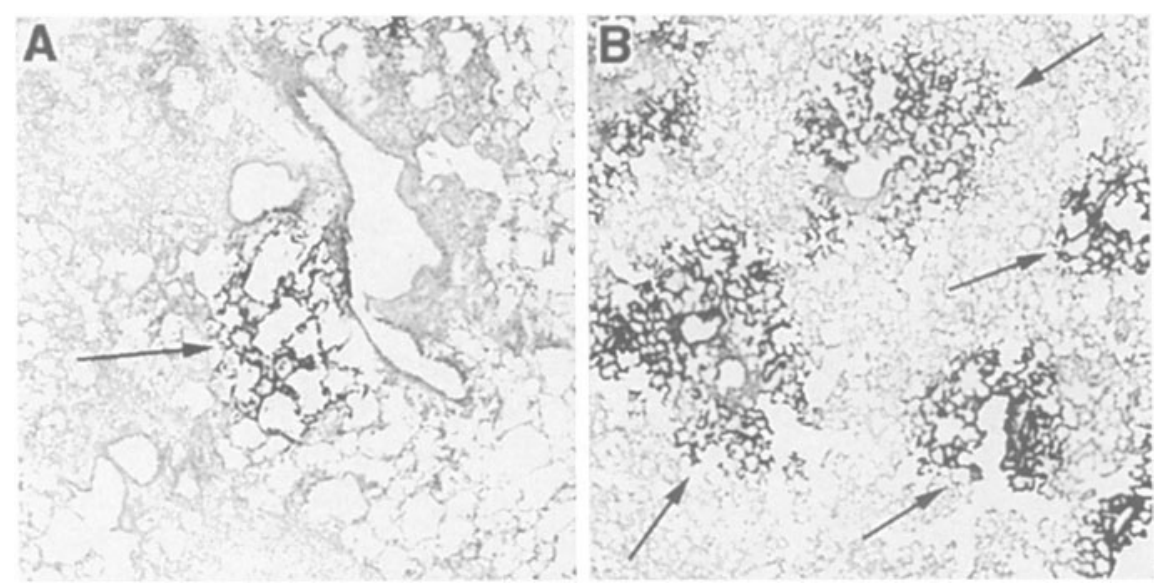

Figure 3 Three days after intratracheal instillation of bleomycin, a second intratracheal instillation of Adlac-Z or Adlac-Z + PFC liquid was performed. Animals were sacrificed 3 days after the second instillation ( 6 days after the initial bleomycin instillation). Rats receiving bleomycin followed by Adlac- $Z$ alone exhibited scattered activity mostly in uninjured lung regions (arrow, $\mathbf{A}$ ). In contrast, rats receiving bleomycin followed by Adlac- $Z$ + PFC liquid exhibited more diffuse activity in both normal and injured lung regions (arrows, B). Original magnification 400x.

Similar observations were made using a model of acute lung injury. Intratracheal instillation of bleomycin sulfate is a well-characterized model of fibrosing lung injury (51). The first several days after bleomycin administration are characterized by acute lung injury consisting of edema, inflammatory cell infiltration, alveolar wall thickening, and epithelial cell desquamation similar to pathologic changes observed in ARDS (52). Instillation of adenoviral vector with PFC liquid to rats one or three days after bleomycin instillation resulted in enhanced total gene expression and better distribution of gene expression than in lungs of bleomycin-injured rats receiving vector alone (Fig. 3). Specifically, gene expression was enhanced in areas of acute lung injury with use of PFC liquids.

\section{Vector-Provoked Inflammatory Responses in Injured Lung: Considerations for the Critically Ill Patient}

Adenoviral vectors trigger dose-dependent acute inflammatory responses when instilled into lung $(40,53,54)$. This innate host antiviral defense is cytokine driven and can result in local and systemic toxicity. Tumor necrosis 
factor- $\alpha$ (TNF $\alpha)$ appears to be an important mediator in this acute response. Treatment of mice with TNF-binding protein decreased lung inflammation and increased the duration of adenoviral-mediated transgene expression in lung and liver (55). Transgenic mice expressing the adenoviral E3-14.7K protein, which blocks TNF $\alpha$-mediated cytotoxicity, in bronchiolar and alveolar epithelial cells exhibited decreased lung inflammation and prolonged transgene expression following adenoviral vector administration (56). Systemic immunosuppression with corticosteroids can also block adenoviral-stimulated lung inflammation (40).

Adenoviral vectors instilled into lung trigger host immune responses. These include cytotoxic (CD8+) T-lymphocyte-dependent responses directed at cells expressing viral or transgenic proteins resulting in chronic inflammation and limited durations of transgene expression $(53,54,57)$. A helper (CD4+) $\mathrm{T}$-lymphocyte-dependent response directed at adenoviral capsid proteins results in generation of neutralizing anti-adenoviral antibodies that can limit the efficacy of adenoviral vector re-administration $(53,54,58)$. Deleting several or all components of the adenoviral genome as well as blocking $\mathrm{T}$ cell mediated immune responses can prolong transgene expression and allow limited vector re-administration (59-62). Similarly, systemic immunosuppression can reduce humoral immune responses and prolong transgene expression $(63,64)$.

However, adenoviral vectors might not provoke further inflammation in the setting of pre-existing lung injury. Instillation of adenoviral vectors into lungs of mice with acute lung inflammation resulting from aerosolized endotoxin resulted in no additional inflammation, as measured by neutrophil accumulation and content of TNF $\alpha$ and IL- 6 in bronchoalveolar lavage (BAL) fluid, compared to mice receiving endotoxin alone (65). These findings suggest that the acute inflammatory effects provoked by adenoviral vectors may be less significant in the setting of pre-existing lung injury.

\section{Anti-Inflammatory Effects of Perfluorochemical Liquids}

PFC liquid instillation has been demonstrated to improve gas exchange, respiratory mechanics, and survival in several animal models of experimentally-induced acute lung injury 42,43 and in patients with acute respiratory distress syndrome (ARDS)(41). PFC liquid instillation has also been shown to attenuate alveolar hemorrhage, edema accumulation, and neutrophil infiltration in lung injury models $(41,46)$. Lavage of injured lungs with PFC liquid has been shown to remove edema fluid and mucus in addition to improving gas exchange and respiratory mechanics $(48,49)$. BAL fluid collected from patients with ARDS undergoing liquid ventilation contained lower concentrations of pro-inflammatory cytokines than did fluid 
from ARDS patients undergoing gas ventilation (31). The mechanism of this latter observation is unknown.

Neutrophils exposed in vitro to PFC liquids subsequently were less able to bind to leukocyte adherence columns or to cultured endothelial cells $(66,67)$. Alveolar macrophages, exposed to PFC liquids in vitro, exhibited decreased spontaneous and endotoxin-stimulated IL-6, IL-8, and $\mathrm{H}_{2} \mathrm{O}_{2}$ release $(68,69)$. The mechanism of these effects is unknown, however, cultured human monocytic cells have been shown to phagocytose PFC liquids (70). We speculate that PFC liquid phagocytosis by alveolar macrophages in vivo may interfere with subsequent ability to secrete pro-inflammatory mediators.

\section{GENE DELIVERY TO OTHER ORGANS IN THE CRITICALLY ILL PATIENT}

A variety of other organs may be more easily accessed in an ICU than in an outpatient or clinic setting. Catheterization of various vascular beds, for example the coronary arteries, pulmonary arteries, and hepatic circulation, and of the central nervous system require invasive maneuvers and specialized equipment often routinely found in intensive care units. These approaches will allow directed gene delivery to specific targets. However, there has been little exploration of gene therapy in this regard in the critically ill patient.

\section{SUMMARY}

Gene therapy for the patient in an intensive care setting is a potentially important new approach for critical illness. In this setting, gene therapy will likely be used more as a pharmacotherapeutic tool for delivering biological mediators than for long term correction of underlying genetic disorders. Although access to various organ systems may be easier in the ICU through use of endotracheal tubes and indwelling catheters, techniques for effective vector delivery to the critically ill patient are underdeveloped.

A likely target for gene therapy in acute illness is the lung. However, current obstacles to successful lung gene therapy include physical barriers impeding vector access to lung epithelium. There are currently no useful clinical strategies for overcoming these barriers using available techniques of direct instillation and aerosol delivery of vectors. Use of PFC liquids offers one potential approach to improving effective gene delivery to injured lungs. However, more investigation is needed to determine if PFC liquids or other approaches will be clinically useful in the critically ill patient. 


\section{LITERATURE CITED}

1. Knowles, MR, Hohneker, KW, Zhaoqing, Z, Olsen, JC, Noah, TL, Hu ,PC, Leigh, MW, Engelhardt, JF, Edwards, LJ, Jones, KR, Grossman, M, Wilson, JM, Johnson, LG, Boucher, RC. A controlled study of adenoviral-vector-mediated gene transfer in the nasal epithelium of patients with cystic fibrosis. $N$ Engl J Med. 1995;333:823-831.

2. Brody, SL, Metzger, M, Danel, C, Rosenfeld, MA, Crystal, RG. Acute responses of non-human primates to airway delivery of an adenovirus vector containing the human cystic fibrosis transmembrane conductance regulator cDNA. Hum Gene Ther. 1994;5:821-836.

3. Simon, RH, Engelhardt, JF, Yang, Y, Zepeda, M, Weber-Pendleton, S, Grossman, M, Wilson, JM. Adenovirus-mediated transfer of the CFTR gene to lung of nonhuman primates: toxicity study. Hum Gene Ther. 1993;4:771-780.

4. Engelhardt, JF, Simon, RH, Yang, Y, Zepeda, M, Weber-Pendleton, S, Doranz, B, Grossman, M, Wilson, JM. Adenovirus-mediated transfer of the CFTR gene to lung of nonhuman primates: biological efficacy study. Hum Gene Ther. 1993;4:759-769.

5. Katkin, JP, Gilbert, BE, Langston, C, French, K, Beaudet, AL. Aerosol delivery of a $\beta$-galactosidase adenoviral vector to the lungs of rodents. Hum Gene Ther. 1995;6:985-995.

6. McDonald, RJ, Lukason, MJ, Raabe, OG, Canfield, DR, Burr, EA, Kaplan, JM, Wadsworth, SC, St.George, JA. Safety of airway gene transfer with Ad2/CFTR2: aerosol administration in the nonhuman primate. Hum Gene Ther. 1997;8:411-422.

7. Sene, C, Bout, A, Imler, JL, Schultz, H, Willemot, JM, Hennebel, V, Zurcher, C, Valerio, D, Lamy, D, Pavirani, A. Aerosol-mediated delivery of recombinant adenovirus to the airways of nonhuman primates. Hum Gene Ther. 1995;6:1587-1593.

8. Zabner, J, Petersen, DM, Puga, AP, Graham, SM, Couture, LA, Keyes, LD, Lukason, MJ, St.George, JA, Gregory, RJ, Smith, AE. Safety and efficacy of repetitive adenovirus-mediated transfer of CFTR cDNA to airway epithelia of primates and cotton rats. Nature Genetics 1994;6:7583.

9. Weiss, DJ, Strandjord, TP, Jackson, JC, Clark, JG, Liggitt, D. Perfluorochemical liquid-enhanced adenoviral vector distribution and expression in lungs of spontaneously breathing rodents. Exp Lung Res. 1999;25:317-333.

10. Crystal, RG, McElvaney, NG, Rosenfeld, MA, Chu, CS, Mastrangeli, A, Hay, JG, Bordy, SL, Jaffe, HA, Eissa, NT, Danel, C. Administration of an adenovirus containing the human CFTR cDNA to the respiratory tract of individuals with cystic fibrosis. Nature Genetics 1994;8:42-51. 
11. Wilson, JM, Engelhardt, JF, Grossman, M, Simon, RH, Yang, Y. Gene therapy of cystic fibrosis lung disease using E1 deleted adenoviruses: a phase I trail. Hum Gene Ther. 2000;5:501-519.

12. Zuckerman, JB, Robinson, CB, McCoy, KS, Shell, R, Sferra, TJ, Chirmule, N, Magosin, SA, Propert, KJ, Brown-Parr, EC, Hughes, JV, Tazelaar, J, Baker, C, Goldman, MJ, Wilson, JM. A Phase I study of adenovirus-mediated transfer of the human cystic fibrosis transmembrane conductance regulator gene to a lung segment of individuals with cystic fibrosis. Hum Gene Ther. 1999;10:2973-2985.

13. Harvey, B-G, Hackett, NR, Ely, S, Crystal, RG. Administration of an E1' /E3 adenovirus vector to airway epithelial cells of normal individuals elicits minimal local host responses. American Society of Gene Therapy 1999.

14. Jobe, AH, Ueda, T, Whitsett, JA, Trapnell, BC, Ikegami, M. Surfactant enhances adenovirus-mediated gene expression in rabbit lungs. Gene Ther. 1996;3:775-779.

15. Katkin, JP, Husser, RC, Langston, C, Welty, SE. Exogenous surfactant enhances the delivery of recombinant adenoviral vectors to the lung. Hum Gene Ther. 1997;8:171-176.

16. Factor, P, Saldias, F, Ridge, K, Dumasius, V, Zabner, J, Jaffe, HA, Blanco, G, Barnard, M, Mercer, R, Perrin, R, Sznajder, JI. Augmentation of lung liquid clearance via adenovirus-mediated transfer of a Na, KATPase betal subunity gene. J Clin Invest. 1998;102:1421-1430.

17. Raczka, E, Kukowska-Latallo, JF, Rymaszewski, M, Chen, C, Baker, JR. The effect of synthetic surfactant Exosurf on gene transfer in mouse lung in vivo. Gene Ther. 1998;5:1333-1339.

18. Tsan, MF, Tsan, GL, White, JE. Surfactant inhibits cationic liposomemediated gene transfer. Hum Gene Ther. 1997;8:817-825.

19. Duncan, JD, Whitsett, JA, Horowitz, AD. Pulmonary surfactant inhibits cationic liposome-mediated gene delivery to respiratory epithelial cells in vitro. Hum Gene Ther. 1997;8:431-438.

20. Wang, G., Davidson, B.L., Melchert, P., Slepushkin, V.A., van Es, H.H.G., Bodner, M., Jolly, D.L., McCray, P.B. Influence of cell polarity on retrovirus-mediated gene transfer to differentiated human airway epithelial epithelia. $J$ Virol. 1998;72, 9818-9826.

21. Walters, RW, Grunst, T, Bergelson, JM, Finberg, RW, Wlesh, MJ, Zabner, J. Basolateral localization offiber receptors limits adenovirus infection of airway epithelia. J Biol Chem. 1999;274, 10219-10226.

22. Duan, D, Yue, Y, Yan, Z, McCray, PBJ, Engelhardt, JF. Polarity influences the efficiency of recombinant adenoassociated virus infection in differentiated airway epithelia. Hum Gene Ther. 1998;9:2761-2776. 
23. Parsons, DW, Grubb, BR, Johnson, LG, Boucher, RC. Enhanced in vivo airway gene transfer via transient modification of host barrier properties with a surface-active agent. Hum Gene Ther. 1998;9:2661-2672.

24. Wang, G, Zabner, J, Deering, C, Launspach, J, Shao, J, Bodner, M, Jolly, DJ, Davidson, BL, McCray, PBJ. Increasing epithelial junction permeability enhances gene transfer to airway epithelia in vivo. $A m J$ Respir Cell Mol Biol. 2000;22:129-138.

25. Chu, Q, Lukason, M, Fang, SL, Tousignant, JD, Jiang, C, St.George, JA. Enhancement of adenovirus-mediated gene transfer to columnar epithelial cells in mouse trachea by EGTA. Proceedings of the American Society of Gene Therapy Meeting 1999.

26. Lee, JH, Zabner, J, Welsh, MJ. Delivery of an adenovirus vector in a calcium phosphate coprecipitate enhances the therapeutic index of gene transfer to airway epithilia. Hum Gene Ther. 1999;10:603-613.

27. Walters, RW, Duan, D, Engelhardt, JF, Welsh, MJ. Incorporation of AAV in a calcium phosphate coprecipitate improves gene transfer to the airway epithelia in vitro and in vivo. Ped. Pulmon. 1999;1:a236.

28. Clark, LC, Jr., Gollan, F. Survival of Mammals Breathing Organic Liquids Equilibrated with Oxygen at Atmospheric Pressure. Science 1966;152:1755-1756.

29. Shaffer, TH, Wolfson, MR, Clark, LC: Liquid Ventilation. Ped. Pulmon. 1992;102-109

30. Leach, CL, Greenspan, JS, Rubenstein, SD, Shaffer, TH, Wolfson, MR, Jackson, JC, DeLemos, R, Fuhrman, BP. Partial liquid ventilation With Perflubron in Premature Infants With Severe Respiratory Distress Syndrome. N Engl J Med. 1996;335:761-767.

31. Croce, MA, Fabian, TC, Patton, JH, Melton, SM, Moore, M, Trenthem, LL. Partial liquid ventilation decreases the inflammatory response in the alveolar environment of trauma patients. J Trauma 1998;45:273-282.

32. Lisby, DA, Ballard, PL, Fox, WW, Wolfson, MR, Shaffer, TH, Gonzales, LW. Enhanced Distribution of Adenovirus-Mediated Gene Transfer to Lung Parenchyma by Perfluorochemical Liquid. Hum Gene Ther. 1997;8:919-928.

33. Weiss, DJ, Niven, RW, Strandjord, TP, Liggitt, D, Clark, JG. Perfluorochemical liquid-enhanced liposomal-mediated gene transfer to lungs of spontaneously breathing rats. Ped Pulmon. 1998;17:269.

34. Weiss, DJ, Munson, K, Strandjord, TP, Lynch, CM. Improved detection of AAV transduction in lung and further augmentation with perfluorochemical liquids. Proceedings of the American Society of Gene Therapy Meeting 1999;(Abstract).

35. Weiss, DJ, Strandjord, TP, Bonneau, L, Liggitt, D, Lukason, M, St.George, J. Enhanced adenoviral-mediated gene expression in lung: 
altered inflammatory response to adenoviral vectors with use of perfluorochemical (PFC) liquids. Ped Pulmon. 1999;Suppl. 19:228.

36. Stern, M, Caplen, NJ, Browning, JE, Griesenbach, U, Sorgi, F, Huang, L, Gruenert, DC, Marriot, C, Crystal, RG, Geddes, DM, Alton, EW. The effect of mucolytic agents on gene transfer across a CF sputum barrier in vitro. Gene Ther. 1998;5:91-98.

37. Arcasoy, SM, Latoche, J, Gondor, M, Watkins, SC, Henderson, RA, Hughey, R, Finn, OJ, Pilewski, JM. MUC1 and other sialoglycoconjugates inhibit adenovirus-mediated gene transfer. $\mathrm{Am} J$ Respir Cell Mol Biol. 1997;17:422-435.

38. Kitson, C, Angel, B, Judd D, Rothery, S, Severs, NJ, Dewar, A, Huang, L, Wadsworth, SC, Cheng, SH, Geddes, DM, Alton, EWFW. The extraand intracellular barriers to lipid and adenovirus-mediated pulmonary gene transfer in native sheep airway epithelium. Gene Ther. 1998;6:534546.

39. van Heeckeren, A, Ferkol, T, Tosi, M. Effects of bronchopulmonary inflammation induced by pseudomonas aeruginosa on adenovirusmediated gene transfer to airway epithelial cells in mice. Gene Ther. 1998;5:345-351.

40. Otake, K, Ennist, DL, Harrod, K, Trapnell, BC. Nonspecific inflammation inhibits adenovirus-mediated pulmonary gene transfer and expression independent of specific acquired immune responses. Hum Gene Ther. 1998;9:2207-2222.

41. Hirschl, RB, Tooley, R, Parent, AC, Johnson, K, Bartlett, RH. Improvement of gas exchange, pulmonary function, and lung injury with partial liquid ventilation. Chest 1995;108:500-508.

42. Tutunco, AS, Faithfull, NS, Lachmann, B. Intratracheal perfluorocarbon administration combined with mechanical ventilation in experimental respiratory distress syndrome: dose-dependent improvement of gas exchange. Crit Care Med. 1993;21:962-969.

43. Papo, MC, Paczan, PR, Fuhrman, BP, Steinhorn, DM, Hernan, LJ, Leach, CL, Holm, BA, Fisher, JE, Kahn, BA. Perfluorocarbon-associated gas exchange improves oxygenation, lung mechanics, and survival in a model of adult respiratory distress syndrome. Crit Care Med. 1996;24:466-474.

44. Bruch, LA, Flint, A, Hirschl, RB. Pulmonary pathology of patients treated with partial liquid ventilation. Mod Path. 1997;10:463-468.

45. Rotta, AT, Gunnarsson, B, Hernan, LJ, Fuhrman, BP, Steinhorn, DM. Partial liquid ventilation influences pulmonary histopathology in an animal model of acute lung injury. J Crit Care. 1999;14:84-92.

46. Colton, DM, Till, GO, Johnson, KJ, Dean, SB, Bartlett, RH, Hirschl, ${ }^{86} \mathrm{Rb}^{+}$. Neutrophil accumulation is reduced during partial liquid ventilation. Crit Care Med. 1998;26:1716-1724. 
47. Rotta, AT, Steinhorn, DM. Partial liquid ventilation reduces pulmonary neutrophil accumulation in an experimental model of systemic endotoxemia and acute lung injury. Crit Care Med. 1998;26:1707-1715.

48. Richman, PS, Wolfson, MR, Shaffer, TH. Lung lavage with oxygenated perfluorochemical liquid in acute lung injury. Crit Care Med. 1993;21:768-774.

49. Cindrick, LL, Gore, DC, Herndon, DN, Traber, LD, Traber, DL. Bronchoscopic lavage with perfluorocarbon decreases postprocedure hypoxemia in an ovine model of smoke inhalation. $J$ Trauma. 1999;46:129-135.

50. Weiss, DJ, Strandjord, TP, Liggitt, D, Clark, JG. Perflubron enhances adenoviral-mediated gene expression in lungs of transgenic mice with chronic alveolar filling. Hum Gene Ther. 1999;10:2287-2293.

51. Weiss, DJ, Strandjord, TP, Liggitt, D, Clark, JG. Enhanced adenoviralmediated gene delivery to lungs of rats with acute bleomycin-induced lung injury usiong perflurochemical liquids. Am J Resp Crit Care Med. 1999;159:A434.

52. Usuki, J, Fukuda, Y. Evolution of three patterns of intra-alveolar fibrosis produced by bleomycin in rats. Path Int. 1995;45:552-564.

53. Look, DC, Brody, SL. Engineering viral vectors to subvert the airway defense response. Am J Resp Crit Care Med. 1999;20:1103-1106.

54. Bromberg, JS, Debruyne, LA, Qin, L. Interactions between the immune system and gene therapy vectors: Bidirectional regulation of response and expression. Adv Immunol. 1998;69:353-409.

55. Zhang, H-G, Zhou, T, Yang, P, Edwards, CKI, Curiel, DT, Mountz, JD. Inhibition of tumor necrosis factor a decreases inflammation and prolongs adenovirus gene expression in lung and liver. Hum Gene Ther. 1998;9:1875-1884.

56. Harrod, KS, Hermiston, TW, Trapnell, BC, Wold, WSM, Whitsett, JA. Lung-specific expression of adenovirus E3-14.7K in transgenic mice attenuates adenoviral vector-mediated lung inflammation and enhances transgene expression. Hum Gene Ther. 1998;9:1885-1898.

57. Song, W, Kong, H-L, Traktman, P, Crystal, RG. Cytotoxic T lymphocyte responses to proteins encoded by heterologous transgenes trasferred in vivo by adenoviral vectors. Hum Gene Ther. 1997;8:1207-1217.

58. Chirmule, N, Propert, KJ, Magosin, SA, Qian, Y, Wilson, JM. Immune responses to adenovirus and adeno-associated virus in humans. Gene Ther. 1996;6:1574-1583.

59. Engelhardt, JF, Litzky, L, Wilson, JM. Prolonged transgene expression in cotton rat lung with recombinant adenoviruses defective in E2a. Hum Gene Ther. 1994;5:1217-1229.

60. Kolls, JK, Lei, D, Odom, G, Nelson, S, Summer, WR, Gerber, MA, Shellito, JE. Use of transient CD4 lymphocyte depletion to prolong 
transgene expression of E1-deleted adenoviral vectors. Hum Gene Ther. 1996;7:489-497.

61. Scaria, A, St.George, JA, Gregory, RJ, Noelle, RJ, Wadsworth, SC, Smith, AE, Kaplan, JM. Antibody to CD40 ligand inhibits both humoral and cellular immune responses to adenoviral vectors and facilitates repeated administration to mouse airway. Gene Ther.1997;4:611-617.

62. Dedieu JF, Vigne E, Torrent C, Jullien C, Mahfouz E, Caillaud JM, Aubailly N, Orsini C, Guillaume JM, Opolon P, Dela re P, Perricaudet $\mathrm{M}$, Yeh P. Long-term gene delivery into the livers ofimmunocompetent mice with E1/E4-defective adenoviruses. J Virol. 1997;71:4626-4637.

63. Bouvet M, Fang B, Ekmekcioglu S, Ji L, Bucana CD, Hamada K, Grimm EA, Roth JA. Suppression of the immune response to an adenovirus vector and enhancement of intratumoral transgene expression by lowdose etoposide. Gene Ther. 1998;5:189-195.

64. Kaplan JM, Smith AE. Transient immunosuppression with deoxyspergualin improves longevity of transgene expression and ability to readminister adenoviral vector to the mouse lung. Hum Gene Ther. 1997;8:1095-1104.

65. Thorne PS, McCray PB, Howe TS, O'Neill MA. Early-onset inflammatory responses in vivo to adenoviral vectors in the presence or absence of lipopolysaccharaide-induced inflammation. Am J Respir Cell Mol Biol. 1999;20:1155-1164.

66. Varani J, Hirschl RB, Dame M, Johnson K. Perfluorocarbon protects lung epithelial cells from neutrophil-mediated injury in an in vitro model of liquid ventilation therapy. Shock 1996;6:339-344.

67. Babbitt DG, Forman MB, Jones R, Bajaj AK, Hoover RL. Prevention of neutrophil-mediated injury to endothelial cells by perfluorochemical. $\mathrm{Am}$ J Patho.l 1990;136:451-459.

68. Thomassen MJ, Buhrow LT, Wiedemann HP. Perflubron decreases inflammatory cytokine production by human alveolar macrophages. Crit Care Med. 1997;25:2045-2047.

69. Smith TM, Steinhorn DM, Thusu K, Fuhrman BP, Dondona P. A liquid perfluorochemical decreases the in vitro production of reactive oxygen species by alveolar macrophages. Crit Care Med. 1995;23:1533-1539.

70. Smith DJ, Kornbrust ES, Lane TA. Phagocytosis of a fluorescently labeled perflubron emulsion by a human monocyte cell line. Artif Cells Blood Substit Immobil Biotechnol. 1994;22:1215-1221. 